\title{
PERLINDUNGAN KONSUMEN ATAS JUAL BELI RUMAH DI KOTA MAKASSAR
}

\author{
Ashar Sinilele \\ Universitas Islam Negeri Alauddin Makassar
}

\begin{abstract}
The legal relationship that arises in the sale and purchase utilization of houses between consumers and developers not only takes place due to an agreement (binding sale and purchase agreement), but also arises because of the provisions of the law (legal engagement relationship). The legal relationship takes place at each transaction process/stage, both the pre-transaction stage, the transaction stage and the post/transactional stage. The legal relationship takes place at every transaction process/stage, so that legal protection must also be obtained by each consumer in each transaction stage. Legal protection for consumer rights in the process of buying and selling stages and ownership of residential houses has been regulated and stated in various legal provisions and legislation consisting of the Civil Code, Law number 8 of 1999 concerning Consumer Protection, Law number 4 of 1992 concerning Housing and Settlements, and Law Number 18 of 1999 concerning Construction Services. To realize consumer protection is carried out as a joint effort based on the principle of benefits, the principle of justice, the principle of balance, the principle of security and the principle of legal certainty.
\end{abstract}

Keywords: Consumer Protection, Legal Relationship, Sale and Purchase.

\begin{abstract}
Abstrak
Hubungan hukum yang timbul dalam jual beli dan pemanfaatan rumah antara konsumen dan developer tidak hanya berlangsung karena adanya perjanjian (perjanjian pengikatan jual beli) semata, tetapi juga timbul karena ketentuan undang-undang (hubungan hukum perikatan). Hubungan hukum tersebut berlangsung pada setiap proses/tahapan transaksi, baik tahap pra transaksi, tahap transaksi maupun tahap purna/pascatransaksi. Hubungan hukum tersebut berlangsung pada setiap proses/tahapan transaksi, sehingga perlindungan hukum harus pula diperoleh setiap konsumen dalam setiap tahapan transaksi. Perlindungan hukum atas hak-hak konsumen dalam proses tahapan jual beli dan pemilikan rumah tinggal telah diatur dan tercantum dalam berbagai ketentuan hukum dan perundang-undangan yang terdiri dari Kitab Undang-Undang Hukum Perdata, Undang-Undang No. 8 Tahun 1999 tentang Perlindungan Konsumen, Undang-Undang No. 4 Tahun 1992 tentang Perumahan dan Permukiman, dan Undang-Undang Nomor 18 Tahun 1999 tentang Jasa Konstruksi. Untuk mewujudkan perlindungan konsumen diselenggarakan sebagai usaha bersama
\end{abstract}


berdasarkan asas manfaat, asas keadilan, asas keseimbangan, asas keamanan dan asas kepastian hukum.

Kata Kunci : Hubungan Hukum, Jual Beli, Perlindungan Konsumen.

\section{PENDAHULUAN}

Sebagaimana dalam Pasal 5 ayat (1) Undang-Undang No. 4 Tahun 1992 tentang Perumahan dan Permukiman (Undang-Undang Perumahan dan Permukiman) bahwa setiap warga negara mempunyai hak untuk menempati dan/atau menikmati dan/atau memiliki rumah yang layak dalam lingkungan yang sehat, aman.

Seiring dengan perkembangan pembangunan permukiman yang dibangun oleh developer secara terpadu yang dibarengi dengan derasnya promosi iklan perumahan di berbagai media massa yang menjanjikan berbagai macam bonus dan fasilitas permukiman secara terpadu, mendorong masyarakat lebih cenderung untuk membeli rumah di lokasi permukiman dengan harapan untuk memperoleh kawasan rumah tinggal yang terpadu dengan fasilitas permukiman yang nyaman, aman dan asri dalam lingkungan yang sehat.

Pengalaman yang sama dialami Agustan. Yang mana telah membeli sebuah rumah di salah satu lokasi permukiman di Makassar. Setelah masuk rumah dan melakukan pengembangan pada beberapa bagian rukonya, alangkah kecewanya setelah melihat bahwa kayu plafond dan atap yang digunakan oleh developer untuk membangun rumah tersebut tidak sesuai dengan spesifikasi teknis seperti yang ditawarkan dalam brosur. Agustan mencoba untuk mengajukan complain hal tersebut kepada pihak developer, tetapi ternyata tidak mendapat tanggapan yang serius, sehingga dengan terpaksa harus mengganti seluruh kayu yang ada pada bagian plafond dan atap rumah. Tentu saja harus mengeluarkan biaya tambahan untuk melakukan renovasi rumah tersebut.

Demikian pula sarana dan prasarana pendukung seperti penyediaan sarana air bersih, listrik, tempat pembuangan sampah, jalan, selokan dan drainase, lampu penerang jalan dan sarana lainnya seperti sarana ibadah, olah raga, sarana pendidikan belum atau tidak kunjung di bangun oleh developer sesuai janjinya pada saat penawaran perdana kepada konsumen, dan hengkang begitu saja setelah proyek selesai. Padahal, dalam Permendagri Nomor 1 tahun 1997 ditegaskan bahwa dalam mengembangkan suatu kawasan permukiman pengembang harus menyediakan prasarana lingkungan, fasilitas umum (fasum) dan fasilitas sosial (fasos).

Selain itu, banyak pula developer tidak mempedulikan pelayanan purna jual dan pengelolaan, Seperti penyediaan dan pengelolaan sarana air bersih, pemeliharaan lampu penerangan jalan, perbaikan dan pemeliharaan jalan serta 
selokan sehingga menimbulkan banjir, pemeliharaan taman dan ruang terbuka hijau, sarana pengamanan (satpam) dan sarana-sarana pendukung lainnya.

\section{METODE PENELITIAN}

Penelitian dilakukan di Kota Makassar karena banyaknya sentra permukiman yang dibangun oleh developer di kota Makassar yang dipicu oleh jumlah developer yang cukup besar, sehingga bagi calon peneliti menentukan dan mengarahkan sasaran penelitian.

\section{PEMBAHASAN}

\section{A. Hubungan Hukum Antara Konsumen Dengan Developer Dalam Jual Beli Rumah di Kota Makassar}

Salah satu norma hukum yang mengatur hubungan hukum di luar ketentuan KUHPerdata yaitu norma-norma hukum yang diatur dalam Undang-Undang Perumahan dan Permukiman serta Undang-Undang Nomor 8 Tahun 1999 tentang Perlindungan Konsumen (UUPK).

Dalam kaitannya dengan perlindungan hukum bagi konsumen, di dalam UUPK telah diatur berbagai norma-norma hubungan hukum antara konsumen dengan pelaku usaha. Norma-norma hubungan hukum dalam UUPK ini telah memberikan kedudukan yang seimbang antara pelaku usaha dan konsumen. Norma-norma tersebut sekaligus merupakan norma-norma perlindungan kepada konsumen dalam hubungan hukum dengan pelaku usaha, yang menurut Yusuf Shofie (2003:10) dikelompokkan sebagai berikut:

1. Kegiatan produksi dan/atau perdagangan barang dan/atau jasa;

2. Kegiatan penawaran, promosi, dan periklanan barang dan/atau jasa ;

3. Kegiatan transaksi penjualan barang dan/atau jasa;

4. Kegiatan pasca transaksi penjualan barang dan/atau jasa.

Dalam hubungan hukum jual beli dan pemanfaatan rumah tinggal antara konsumen dan developer, pengelompokan norma-norma tersebut tercermin dalam setiap tahapan atau proses hubungan hukum, yang meskipun hubungan hukum jual beli rumah tinggal antara konsumen dan developer didasarkan pada suatu perjanjian (perjanjian jual beli), namun ketentuan-ketentuan di dalam UndangUndang Perumahan dan Permukiman serta UUPK tidak dapat dikesampingkan begitu saja sebagai norma-norma hukum perikatan yang lahir dari undang-undang yang berlaku sebagai hukum publik.

Dari keseluruhan proses/tahapan kegiatan developer yang digambarkan di atas, maka hubungan hukum antara developer dan konsumen dapat dibagi 
kedalam tiga tahapan transaksi, yaitu pada tahap pra transaksi, tahap transaksi dan tahap purna/pascatransaksi, dengan penjelasan sebagai berikut:

1. Tahap Pra Transaksi

Tahap pra transaksi yang meliputi kegiatan perizinan dan produksi, kegiatan penawaran, promosi dan periklanan (brosur, iklan, pameran) merupakan tahap awal kegiatan developer untuk memulai rencana pengembangan wilayah permukiman.

Sebelum developer melakukan kegiatan produksi, maka kegiatan developer didahului dengan persiapan pendahuluan, berupa:

a. Kelengkapan perizinan

Pada tahap ini, kegiatan developer diawali dengan pengurusan kelengkapan perizinan pada instansi pemerintah setempat. Pengurusan kelengkapan perizinan ini merupakan tahapan penting bagi developer dan konsumen dalam melakukan hubungan hukum jual beli rumah tinggal. Kelengkapan perizinan ini merupakan persyaratan administratif yang dibebankan oleh Pemerintah Daerah/Kota dan Kantor Pertanahan setempat kepada developer.

Dari hasil penelitian dapat dijelaskan bahwa bentuk perizinan yang lasim dan harus disiapkan developer adalah sebagai berikut:

1) Izin Prinsip

Izin prinsip merupakan salah satu bentuk perizinan yang sangat prinsipil yang harus diperhatikan dan dimiliki developer sebelum memulai kegiatan dalam pengembangan permukiman. Izin prinsip dimaksudkan untuk menyesuaikan rencana pembangunan dan penataan ruang kota jangka panjang, sehingga pengaturan peruntukan suatu lokasi atau wilayah tidak semrawut dan tidak melanggar prinsip-prinsip penataan kota dalam Rencana Umum Tata Ruang Kota (RUTRK) dan Rencana Bagian Wilayah Kota (RBWK).

Dalam pemberian rekomendasi izin prinsip ini yang terpenting adalah adanya persyaratan penggunaan lahan, yaitu pertimbangan perbandingan penggunaan lahan yakni $40 \%$ untuk prasarana dan open space, fasilitas/sarana umum yang terdiri dari penggunaan lahan untuk jalan, saluran pembuangan air hujan, saluran pembuangan air limbah, sarana pendidikan, sarana kesehatan, sarana peribadatan, sarana olah raga, ruang terbuka hijau (taman), sarana kebersihan dan sarana keamanan, sedangkan penggunaan lahan $60 \%$ digunakan untuk bangunan fisik (bangunan rumah).

2) Izin Lokasi 
Setelah izin prinsip diberikan dan dimiliki developer, maka selanjutnya developer harus menentukan lokasi mana yang akan dijadikan prioritas pengembangan permukiman/ perumahan dalam rangka melakukan kegiatan pengadaan tanah. Izin prinsip yang telah dimiliki selanjutnya ditindaklanjuti dalam bentuk izin lokasi atas wilayah tanah yang akan dibebaskan. Lokasi yang menjadi rencana prioritas pengembangan tidak boleh keluar dari wilayah izin prinsip yang diberikan.

Dalam pemberian izin lokasi ini, Kantor Pertanahan mendasarkan pertimbangan bahwa developer yang mengajukan permohonan telah mendapat izin prinsip dari Pemerintah Daerah/Kota setempat, dan wilayah yang dimohonkan memungkinkan dan dapat dikembangkan sebagai daerah permukiman/perumahan. Pertimbangan lainnya adalah bahwa pemohon izin lokasi telah dilengkapi persyaratan dan ketentuan untuk memperoleh surat keputusan izin lokasi, seperti hasil survey AMDAL dan Master Plan developer atau bukti kepemilikan hak atas tanah bagi developer yang telah memiliki hak atas tanah di atas izin lokasi yang akan dimohonkan.

Sebelum memberikan izin lokasi, Kantor Pertanahan akan melakukan survey lokasi yang dimohonkan, serta membuat peta lokasi tanah yang akan diberikan izin, yang selanjutnya dituangkan dalam suatu keputusan pemberian izin lokasi. Isi surat keputusan Kantor Pertanahan akan dilampiri dengan peta lokasi tanah, dengan syarat dan ketentuan sebagai berikut:

1. Perolehan tanah harus dilakukan secara langsung antara pihak-pihak yang berkepentingan melalui jual beli atau dengan cara pelepasan hak yang dilaksanakan di hadapan Kepala Kantor Pertanahan setempat dengan pemberian ganti kerugian yang bentuk dan besarnya ditentukan secara musyawarah;

2. Pembayaran ganti kerugian tanah serta tanaman tumbuh dan atau bangunan yang ada di atasnya ataupun barang-barang lain untuk pemegang hak atas tanah tidak dibenarkan dilaksanakan melalui perantaraan dalam bentuk dan nama apapun kepada yang berhak;

3. Perolehan tanah harus diselesaikan dalam jangka waktu 12 (dua belas) bulan sejak tanggal ditetapkan surat keputusan pemberian izin lokasi dan dapat diperpanjang paling lama 12 (dua belas) bulan dan dilaporkan perkembangannya oleh penerima izin lokasi kepada 
Kepala Kantor Pertanahan setempat dengan tembusan kepada Kepala Kantor Wilayah Badan Pertanahan Nasional Propinsi setempat;

Persoalan yang sering terjadi dengan diterbitkannya sertifikat kavling ini, yakni apabila proyek yang dibangun developer di biayai oleh pinjaman bank dengan jaminan sertifikat induk, maka baik sisa luasan sertifikat induk maupun sertifikat pecahan/kavling tersebut harus diserahkan ke bank sebagai jaminan utang, yang meliputi tanah dan seluruh bangunan rumah tinggal yang ada di atasnya, sehingga untuk melakukan pengalihan hak dan meyerahkan bukti hak kepada konsumen, developer harus menempuh proses penebusan terlebih dahulu dengan menyerahkan sejumlah dana kepada bank untuk menarik sertifikat. Hal ini banyak terjadi pada penjualan rumah secara tunai. Nilai tebusan/setoran satu sertifikat kavling pada bank yang harus diserahkan/disetorkan developer tergantung dari kesepakatan dalam perjanjian kredit bank yang disesuaikan dengan besarnya nilai plafond kredit yang diberikan kepada developer.

Untuk menghindari kemungkinan risiko tersebut di atas, maka sebaiknya sebelum konsumen melakukan pembayaran pelunasan harga sesuai perjanjian (PPJB), maka terlebih dahulu harus menanyakan dan melihat sendiri apakah sertifikat pecahan/kavling sebagai objek rumah tinggal tersebut sudah tersedia. Karena bila tidak, maka kesulitan akan diderita konsumen di kemudian hari.

Janji-janji developer untuk membangun dan menyediakan sarana/fasilitas permukiman kepada konsumen pada saat penawaran perdana ini berupa fasilitas umum seperti: pembangunan sarana jalan, lampu penerangan jalan, sarana hiburan, sarana perbelanjaan/perdagangan (ruko/toko), penyediaan sarana air bersih, instalasi listrik dan pengamanan lingkungan permukiman, taman bermain anak-anak, serta fasilitas sosial seperti: sarana rumah ibadah (mesjid, gereja), sarana olah raga dan sarana pendidikan (sekolah).

2. Tahap Transaksi

Proses hubungan hukum pada tahap ini didasarkan pada perjanjian jual beli antara konsumen dan developer sebagaimana diatur dalam Pasal 1457 1518 KUHPdt. Hubungan hukum dalam jual beli ini akan berlangsung baik secara tunai maupun dengan kredit dengan melibatkan berbagai pihak, dan mengikuti berbagai prosedur dan ketentuan hukum yang tersebar di luar ketentuan KUHPdt, seperti ketentuan Undang-Undang Nomor 4 tahun 1996 tentang Hak Tanggungan, Peraturan Pemerintah Nomor 37 Tahun 1998 tentang Peraturan Jabatan Pejabat Pembuat Akta Tanah, Undang-Undang Nomor 24 tahun 1997 tentang Pendaftaran Tanah, ketentuan tentang tugas dan wewenang Badan Pertanahan Nasional, serta berbagai ketentuan tentang perpajakan 
(seperti Pajak Pertambahan Nilai, Pajak Penghasilan dan Pajak Bea Perolehan Hak Atas Tanah dan Bangunan/BPHATB).

Tahapan perbuatan hukum di atas secara rinci dimuat dan menjadi klausula dalam Perjanjian Pengikatan Jual beli unit rumah.

a. Perjanjian Pengikatan Jual Beli (PPJB)

Dalam hubungan hukum jual beli rumah antara konsumen dan developer diawali dengan penandatanganan suatu perjanjian jual beli di bawah tangan dengan bentuk Perjanjian Pengikatan Jual Beli (PPJB) atau Perjanjian Pemesanan Rumah (PPR). Hal ini sesuai dengan amanat diktum kedua Kepmenpera No.09/KPTS/M/1995 tanggal 23 Juni 1995), yang menegaskan bahwa: setiap adanya Pengikatan Jual Beli Rumah wajib mengikuti pedoman Pengikatan Jual Beli Rumah beserta contohnya. Contoh perjanjian Pengikatan Jual Beli Rumah sebagai lampiran Kepmenpera No.09/KPTS/M/1995 dapat dilihat pada bagian lampiran tulisan ini.

Bagi konsumen yang terpenting adalah, menandatangani suatu perjanjian jual beli, karena ketiadaan perjanjian tersebut justru akan lebih melemahkan kedudukan konsumen karena tidak adanya ikatan hukum (alat bukti) secara tertulis atas objek perjanjian jual beli yaitu rumah. Umumnya konsumen tidak terlalu mempersoalkan isi dan materi perjanjian selain dari materi tentang harga dan objek jual beli. Penandatanganan perjanjian ini sangat perlu sebagai bentuk adanya hubungan hukum perjanjian antara konsumen dan developer terhadap objek perjanjian.

b. Mekanisme pembayaran

Selain objek jual beli dan harga jual yang diatur dalam PPJB atau PPR, juga ditentukan mengenai mekanisme pembayaran yang harus dilakukan oleh konsumen. Mekanisme atau aturan pembayaran ini meliputi pembayaran tanda jadi (booking fee), uang muka (down payment), dan pelunasan harga, yang dapat dilakukan konsumen dengan cara sesuai yang telah disepakati dan ditentukan dalam PPJB/PPR. Cara pembayaran dapat dilakukan baik secara tunai (cash keras), angsuran/cicilan (cash bertahap), maupun melalui fasilitas Kredit Pemilikan Rumah (KPR) dari bank. Bentuk pembayaran dapat dilakukan konsumen dengan tunai pada kasir developer, menggunakan media surat berharga (cek, bilyet giro), melalui transfer atau inkaso ke rekening bank atas nama developer atau dengan cara melakukan kompensasi pembayaran bagi konsumen yang bermitra usaha dengan developer. Semua bentuk dan cara pembayaran ini dilakukan sesuai kesepakatan dan persetujuan para pihak. 
Dalam kondisi seperti ini, konsumen harus lebih teliti dan berhati-hati dalam melakukan pembayaran harga. Konsumen harus memperhatikan progress pembayaran dengan progress pembangunan dan penyelesaian bangunan rumah seperti yang ditentukan dalam perjanjian. Karena, umumnya klausula kewajiban pembayaran yang ditentukan developer telah disesuaikan dengan kemampuan developer untuk membangun dan menyelesaikan bangunan rumah. Konsumen harus senantiasa mengontrol kemajuan pekerjaan developer di lapangan agar tidak menyesal di kemudian hari.

c. Pembangunan rumah

Waktu pembangunan dan penyelesaian rumah merupakan saat yang menggembirakan bagi konsumen. Setelah konsumen melakukan pembayaran (tanda jadi, uang muka dan/atau pelunasan harga) sesuai cara dan bentuk pembayaran yang disepakati dalam perjanjian tentu saja konsumen sangat mengharapkan agar rumah yang dibeli segera dibangun dan diselesaikan oleh developer. Kekhawatiran konsumen sering terjadi bila telah membayar harga sedangkan rumah belum atau baru akan dibangun oleh developer.

Beberapa strategi konsumen dalam mencermati persoalan seperti diuraikan di atas, yakni meskipun konsumen mempunyai dana yang cukup untuk melunasi seluruh harga (tidak menggunakan fasilitas KPR) tetapi ada kekhawatiran bahwa developer nantinya tidak melakukan penebusan seritifikat karena pembayaran konsumen digunakan untuk pembiayaan lain oleh developer, maka konsumen mengajukan permohonan fasilitas KPR dalam jangka waktu pendek (1-12 bulan) hanya dengan maksud agar sertifikat dapat diterima melalui bank dan tidak lagi melalui developer.

Setelah sertifikat telah didaftar (dibalik nama) atas nama konsumen, maka sertifikat harus diserahkan kepada konsumen sebagai bukti pemilikan hak atas unit rumah tinggal. Penyerahan sertifikat bukti hak ini merupakan bentuk perlindungan dan jaminan kepastian hukum bagi konsumen. Bagi konsumen yang melakukan pembelian/pembayaran seluruh harga secara tunai, maka developer harus menyerahkan kepada konsumen, sedangkan bagi pembayaran melalui fasilitas KPR, developer harus menyerahkan sertifikat tersebut kepada pihak bank pemberi kredit untuk selanjutnya diserahkan kepada konsumen setelah KPR telah dilunasi.

3. Tahap Purna/Pascatransaksi

a. Layanan Purna Jual 
Layanan purna jual, merupakan layanan yang diberikan developer kepada konsumen setelah penyerahan bangunan rumah dan penyerahan sertifikat dilakukan. Layanan purna jual ini dilakukan developer untuk memberikan layanan prima kepada konsumen. Layanan ini juga merupakan bagian dari teknik dan strategi pemasaran yang dilakukan developer dalam menghadapi para pesaing (competitor) di bidang bisnis ini.

Layanan purna jual dapat berbentuk penyediaan dan pengelolaan air bersih, pengelolaan sampah dan kebersihan lingkungan permukiman, serta pengelolaan petugas pengamanan (satpam). Layanan lainnya seperti pembayaran rekening listrik, rekening air, rekening kebersihan/sampah dan rekening telepon, yang dilakukan baik pada kantor developer atau pada bank yang berada dilokasi permukiman dengan bekerja sama dengan instansi-instansi terkait. Layanan ini diberikan untuk memberikan kemudahan bagi konsumen/penghuni/warga, sehingga tidak perlu lagi jauh membayar ke kota dan harus antrian panjang.

Selain itu, bentuk layanan lainnya seperti: layanan pemasangan jaringan telepon dengan bekerja sama dengan pihak PT.Telkom, pemasangan dan pembersihan AC, pengecatan rumah, memberikan konsultasi perbaikan/pengembangan konstruksi bangunan rumah, penataan interior dan eksterior, pemotongan rumput dan penataan taman, serta layanan perbaikan pada bagian rumah yang telah rusak atau usang. Layanan ini diberikan setelah berakhirnya masa maintenance, yang sewaktu-waktu dikehendaki oleh konsumen.

Dengan melakukan pengelolaan purna jual, developer dapat memperoleh pendapatan untuk menambah omset laba sekaligus untuk membantu menyediakan kesempatan kerja bagi warga sekitar komplek permukiman, di mana gaji diperoleh dari pendapatan layanan purna jual.

Meskipun layanan purna jual ini turut memberi andil dalam promosi dan penawaran, namun ada juga konsumen yang tidak mempedulikan akan layanan ini pada saat memutuskan membeli unit rumah, yang penting dapat memiliki rumah sebagai tempat tinggal.

b. Penyediaan Sarana Permukiman

Pembangunan dan penyediaan sarana permukiman merupakan kewajiban developer. Meskipun hal ini tidak dicantumkan dan diperjanjikan secara tegas di dalam PPJB atau PPR, namun tidak berarti melepaskan tanggung jawab developer untuk membangun sarana dan prasarana lingkungan permukiman, karena pada brosur penawaran yang diedarkan oleh developer termuat janji-janji tersebut secara jelas, 
konsumen mempunyai hak untuk menikmati sarana permukiman, karena brosur merupakan bagian dari perjanjian. Selain di dalam brosur, janji tersebut seringkali disampaikan lebih detil oleh para sales marketing atau pada pamflet atau poster yang dipasang dipinggir jalan raya.

Janji yang disampaikan developer pada berbagai media atau sarana tersebut merupakan bentuk informasi yang sangat mempengaruhi dan mendorong keinginan konsumen untuk membeli rumah tinggal di lokasi permukiman yang dibangun developer. Konsumen tentunya telah mempertimbangkan bahwa harga jual unit rumah yang ditawarkan developer sudah termasuk komponen harga sarana dan prasarana yang harus dibayar dalam harga jual, sehingga konsumen menganggap bahwa dengan pembayaran seluruh harga jual sudah meliputi harga/nilai bangunan rumah dan tanah, sarana dan prasarana serta penataan taman dan tanaman.

Anggapan konsumen memang benar, karena umumnya sebelum menetapkan harga jual per unit rumah tinggal (unit price), developer telah memperhitungkan nilai harga pokok (biaya produksi) dan keuntungan (profit margin) kemudian menetapkan harga jual. Harga pokok atau biaya produksi dapat meliputi biaya overhead, harga dan biaya pengadaan tanah, sertifikasi tanah, biaya pemasaran, bunga pinjaman (jika menggunakan fasilitas pinjaman/Kredit Modal Kerja), biaya bangunan rumah, pajak, serta seluruh komponen biaya sarana dan prasarana yang akan dibangun developer (seperti: sarana akses jalan, selokan dan drainase, taman dan tanaman, serta fasum dan fasos lainnya). Harga pokok ini kemudian dikelompokkan ke dalam tiga komponen biaya produksi yaitu biaya bangunan rumah dan tanah (building), biaya sarana dan prasarana (infrastructure) serta taman dan tanaman tumbuh (landscape).

Setelah memperhitungkan harga pokok dan besarnya persentase keuntungan yang harus diperoleh dari harga per unit (unit price) penjualan rumah, barulah developer dapat menentukan berapa harga jual yang ditawarkan. Penetapan harga jual ini tentu saja telah mempertimbangkan harga pasar dan harga yang ditetapkan oleh para pesaing (competitor) yang ada pada area yang sama. Harga jual unit rumah tinggal di Jakarta tentu saja tidak sama di Makassar, atau daerah lain di luar Makassar, semuanya tergantung dari komponen harga pokok, persentase keuntungan dan kemampuan daya beli masyarakat setempat (harga pasar).

Oleh karena pembayaran harga beli rumah tinggal yang dilakukan konsumen sudah termasuk komponen biaya tersebut, sehingga tidak ada 
alasan bagi developer untuk tidak membangun dan menyediakan sarana dan prasarana permukiman.

Dari berbagai alasan dan dasar hukum yang dikemukakan di atas, maka pembangunan dan penyediaan sarana dan prasarana permukiman tidak dapat dihindari dan dipungkiri oleh setiap developer, oleh karena pembangunan dan penyediaan sarana dan prasarana permukiman merupakan konsekuensi bagi setiap developer (pemerintah atau swasta) bila ingin berbisnis di bidang ini.

Walaupun pembangunan dan penyediaan sarana dan prasarana permukiman diwajibkan bagi developer, namun dalam berbagai peraturan dan perundang-undangan tidak dijelaskan secara tegas mengenai sarana dan prasarana apa saja yang harus dibangun dan disediakan developer. Hal ini merupakan kelemahan dari peraturan dan perundang-undangan di bidang perumahan dan permukiman, sehingga tidak memberikan perlindungan atas hak-hak konsumen untuk menikmati sarana dan prasarana permukiman.

Menurut Direktur Teknik dan Perencanaan PT.BAD bahwa penyediaan sarana dan prasarana permukiman yang telah dibangun developer harus memenuhi ketentuan seperti ditegaskan dalam rekomendasi izin prinsip, yaitu penyediaan sarana permukiman dilakukan dengan perbandingan 40:60, artinya 40\% dari keseluruhan luas lokasi harus dibangun untuk sarana, dan $60 \%$ untuk peruntukan pembangunan rumah. Hal ini dimaksudkan untuk memberikan keseimbangan antara lingkungan alam dengan lingkungan buatan. Bila developer menaati ketentuan ini, maka akan tercipta keserasian dan keseimbangan, baik antara lingkungan buatan dengan lingkungan alam maupun dengan lingkungan sosial budaya di kawasan permukiman sebagai persyaratan ekologis pembangunan permukiman.

c. Pengelolaan dan pemeliharaan lingkungan permukiman

Pengelolaan dan pemeliharaan lingkungan permukiman merupakan salah satu bentuk layanan purna jual yang diberikan developer di kawasan permukiman. Hanya saja, dalam layanan ini developer tidak memberikan layanan jasa secara langsung seperti halnya pada layanan purna jual seperti diuraikan di atas, sehingga developer tidak memungut iuran secara langsung dari konsumen/warga. 


\section{B. Perlindungan Hukum Bagi Konsumen Atas Pemilikan Rumah dari Developer di Kota Makassar}

Perlindungan konsumen adalah segala upaya yang menjamin adanya kepastian hukum untuk memberi perlindungan hukum kepada konsumen (Pasal 1 angka (1) UUPK). Perlindungan hukum merupakan perlindungan atas hak-hak konsumen baik dari pelaku usaha, pemerintah serta institusi hukum dalam kaitannya dengan pemanfaatan atau penggunaan suatu produk barang dan/atau jasa, baik berdasarkan perjanjian maupun menurut peraturan perundang-undangan yang berlaku untuk memberikan jaminan kepastian hukum kepada konsumen sesuai asas perlindungan konsumen.

Untuk mewujudkan perlindungan bagi konsumen, maka perlindungan konsumen diselenggarakan sebagai usaha bersama berdasarkan 5 (lima) asas yang relevan dalam pembangunan nasional (penjelasan Pasal 2 UUPK), yaitu:

1. Asas manfaat dimaksudkan untuk mengamanatkan bahwa segala upaya dalam penyelenggaran perlindungan konsumen harus memberikan manfaat sebesar-besarnya bagi kepentingan konsumen dan pelaku usaha secara keseluruhan;

2. Asas keadilan dimaksudkan agar partisipasi seluruh rakyat dapat diwujudkan secara maksimal dan memberikan kesempatan kepada kosnumen dan pelaku usaha untuk memperoleh haknya dan melaksanakan kewajibannya secara adil;

3. Asas keseimbangan dimaksudkan untuk memberikan keseimbangan antara kepentingan konsumen, pelaku usaha, pemerintah dalam arti materil ataupun spritual;

4. Asas keamanan dan keselamatan konsumen dimaksudkan untuk memberikan jaminan atas keamanan dan keselamatan kepada konsumen dalam penggunaan, pemakaian, dan pemanfaatan barang dan/atau jasa yang dikonsumsi atau digunakan;

5. Asas kepastian hukum dimaksudkan agar baik pelaku usaha maupun konsumen menaati hukum dan memperoleh keadilan dalam penyelenggaraan perlindungan konsumen, serta negara menjamin kepastian hukum.

\section{PENUTUP}

\section{A.Kesimpulan}

Berdasarkan pembahasan diatas maka, disimpulkan sebagai berikut :

1) Hubungan hukum yang timbul dalam jual beli dan pemanfaatan rumah antara konsumen dan developer tidak hanya berlangsung karena adanya perjanjian 
(perjanjian pengikatan jual beli) semata, tetapi juga timbul karena ketentuan undang-undang (hubungan hukum perikatan). Hubungan hukum tersebut berlangsung pada setiap proses/tahapan transaksi, baik tahap pra transaksi, tahap transaksi maupun tahap purna/pascatransaksi.

2) Hubungan hukum tersebut berlangsung pada setiap proses/tahapan transaksi, sehingga perlindungan hukum harus pula diperoleh setiap konsumen dalam setiap tahapan transaksi. Perlindungan hukum atas hak-hak konsumen dalam proses tahapan jual beli dan pemilikan rumah tinggal telah diatur dan tersebar dalam berbagai ketentuan hukum dan perundang-undangan seperti: Kitab Undang-Undang Hukum Perdata, Undang-Undang No. 8 Tahun 1999 tentang Perlindungan Konsumen, Undang-Undang No. 4 Tahun 1992 tentang Perumahan dan Permukiman, Undang-Undang Nomor 18 Tahun 1999 tentang Jasa Konstruksi.

\section{B.Saran -Saran}

1) Konsumen hendaknya dapat mengetahui hak dan kewajibannya dalam setiap proses/tahapan transaksi, lebih teliti dan cermat dalam melakukan seluruh tahapan hubungan hukum agar terhindar dari berbagai macam permasalahan dan risiko dalam jual beli dan pemanfaatan rumah tinggal.

2) Rentannya permasalahan yang dihadapi konsumen dalam pemilikan rumah dari developer, sedangkan ketentuan hukum dan perundang-undangan belum mengatur secara rinci dan tegas tentang perlindungan konsumen dalam pemilikan rumah tinggal dari developer, sehingga diperlukan upaya regulasi tersendiri untuk mengantisipasi perilaku menyimpang developer yang belum dapat dijangkau oleh hukum. 


\section{DAFTAR PUSTAKA}

Ahmadi Miru. Prinsip-Prinsip Perlindungan Hukum Bagi Konsumen di Indonesia. Disertasi. Surabaya: Universitas Airlangga, 2000.

Ahmadi Miru dan Sutarman Yodo. Hukum Perlindungan Konsumen. Jakarta: PT.RajaGrafindo Persada, 2004.

Endang Sri Wahyuni. Aspek Hukum Sertifikasi dan Keterkaitannya dengan Perlindungan Konsumen. Bandung: PT.Citra Aditya Bakti, 2003.

Gunawan Widjaja dan Ahmad Yani. Hukum tentang Perlindungan Konsumen. Jakarta: PT.Gramedia Pustaka Utama, 2001.

Husni Syawali dan Neni Sri Imaniyati. Hukum Perlindungan Konsumen. Bandung: CV.Mandar Maju, 2000.

Nasution, Az. Konsumen dan Hukum, Tinjauan Sosial, Ekonomi dan Hukum pada Perlindungan Konsumen Indonesia. Jakarta: Pustaka Sinar Harapan, 1995.

Parlindungan, A.P. Komentar atas Undang-Undang Perumahan dan Permukiman \& Undang-Undang Rumah Susun. Bandung: CV.Mandar Maju, 2001.

Ronny Hanitijo Soemitro. Metodologi Penelitian Hukum. Jakarta: Ghalia Indonesia, 1983.

Salim, H.S. Perkembangan Hukum Kontrak Innominaat di Indonesia. Jakarta: Sinar Grafika, 2003. ---. Hukum Kontrak, Teori dan Teknik Penyusunan Kontrak. Jakarta: Sinar Grafika, 2003.

Suharnoko. Hukum Perjanjian, Teori dan Analisa Kasus. Jakarta: Prenada Media, 2004.

Yusuf Shofie. Perlindungan Konsumen dan Instrumen-Instrumen Hukumnya. Bandung: PT.Citra Aditya Bakti, 2003. 